\title{
Alguns argumentos contra o inatismo lingüístico ${ }^{1}$
}

\author{
Some arguments against linguistic nativism
}

\section{Edoardo Lombardi Vallauri \\ Università Roma Tre}

\begin{abstract}
In this article the fundamental premises adopted by a human innate language capacity are critically examined. Based on several arguments, the poverty of stimulus principle is challenged along with other claims made by innate views on the so-called language faculty. Arguments that focus on the plausibility of there being general cognitive capacities that allow for language development are set forth, in support of a linguistic developmental view.
\end{abstract}

\section{Keywords}

Poverty of stimulus; Language acquisition device; Universal grammar.

\section{Resumo}

Neste artigo as premissas fundamentais da visão inatista da capacidade lingüística humana são examinadas. Com base em diversos argumentos, o princípio da pobreza de estímulo é desafiado, assim como outros postulados da teoria que defende uma faculdade da linguagem específica. Argumentos que enfocam a plausibilidade de capacidades cognitivas gerais licenciarem o desenvolvimento lingüístico são apresentados.

\section{Palavras-chave}

Pobreza de estímulo; Dispositivo de aquisição da linguagem; Gramática universal. 


\begin{abstract}
linguagem, pelo menos na sua forma plena, ou seja, as línguas, é uma prerrogativa da espécie homo sapiens sapiens. Isso admite duas explicações. A primeiraé que as línguas sejam modalidades convencionais para interagir, que somente a nossa espécie desenvolveu historicamente, como acontece para a matemática, a religião, o urbanismo, a etiqueta, os esportes, a tecnologia. A segunda hipótese é que, contrariamente a essas outras coisas, a linguagem não seja somente um produto histórico, mas seja em primeiro lugar uma dotação orgânica de cada indivíduo humano.

Segundo a primeira hipótese, o cérebro e a mente de cada indivíduo humano são dotados de capacidades suficientes para gerenciar um instrumento complexo como a linguagem, mas não de estruturas que possam ser consideradas especificamente lingüísticas; portanto o desenvolvimento coletivo dessa habilidade fundamental do comportamento humano se baseia nas mesmas características gerais (memória, capacidade de solucionar problemas, capacidade de gerenciar estruturas recursivas, e similare ${ }^{2}$ ) nas quais se baseiam as outras habilidades das quais o homem é dotado ou se dotou.

De acordo com a segunda hipótese, que o cérebro humano hospeda um módulo dedicado à linguagem, cuja função é especificamente a de permitir o desenvolvimento dela em cada indivíduo humano. ${ }^{3}$ Em outras palavras, a gramática de cada língua, pelo menos em certa medida, não seria uma convenção entre indivíduos, mas uma dotação de cada indivíduo. A faculdade da linguagem seria inata.
\end{abstract}

\title{
1. Pobreza do estímulo
}

Segundo Chomsky, que tem defendido a tese inatista em muitos de seus escritos, postular uma gramática inata, presente no cérebro ao nascimento, é necessário para explicar a aquisição da linguagem por parte das crianças. A 
linguagem seria complexa demais para que um indivíduo possa "extrapolá-la" a partir dos dados aos quais está exposto durante o crescimento, ou seja, as produções das pessoas que a circundam. Esses dados, de fato, seriam poucos, contraditórios, incompletos. Citando Bertrand Russell, Chomsky (1987) põe essa pergunta retórica:

How do we come to have such rich and specific knowledge, or such intricate systems of belief and understanding, when the evidence available to us is so meagre? ${ }^{4}$

A idéia de que o tempo e o material lingüístico à disposição das crianças durante a aquisição da linguagem sejam insuficientes para explicar a rapidez com que elas se empossam de um instrumento tão complexo toma o nome de Argumento da pobreza do estímulo (Argument from the Poverty of the Stimulus). Foi formulado assim por Cecchetto e Rizzi (2000, p. 119):

Humans acquire a natural language early in life, without specific instruction, apparently in a non-intentional manner, with limited individual variation in spite of the fragmentary and individually variable courses of experience which ground individual knowledge of language. More importantly, the precise understanding of fragments of the adult knowledge of language reveals the massive presence of "poverty of stimulus" situations: our adult knowledge of language is largely underdetermined by the data available in childhood, which would be consistent with innumerable generalizations over and above the ones that speakers seem to unerringly converge to. This empirical observation is of great importance, as it grounds the necessity of postulating a structured system of predetermined linguistic principles which guide language acquisition; it also leads to the expectation of a fundamental crosslinguistic uniformity of human languages. ${ }^{5}$

Nesse Argumento se funda, portanto, a opinião de que a linguagem seja inata enquanto tal, ou seja, que o cérebro não contenha somente genéricas capacidades de memória, de elaboração lógico-simbólica e de solucionar problemas, ${ }^{6}$ mas o que Chomsky chama um verdadeiro Language Acquisition Device (LAD), um “instrumento para a aquisição da linguagem”. Esse LAD não 
seria outra coisa, de fato, que uma verdadeira gramática, graças à qual cada input que chega à criança durante a aquisição seria imediatamente reconhecido e colocado em seu próprio lugar na estrutura da linguagem que preexiste no cérebro; isso não poderia acontecer se o cérebro fosse, lingüisticamente falando, uma tabula rasa:

there is little hope in accounting for our [linguistic] knowledge in terms of such ideas as analogy, induction, association, reliable procedures, good reasons, and justification [...] or in terms of "generalized learning mechanisms" [...] We should, so it appears, think of knowledge of language as a certain state of the mind/brain [...] some distinguishable faculty of the mind - the language faculty - with its specific properties, structure, and organization, one "module" of the mind. (CHOMSKY, 1986, p. 12)

Naturalmente esse módulo-gramática deve ser universal (uma Universal Grammar: GU), ou seja, comum a todas as línguas; contrariamente não se explicaria o fato de que qualquer criança adquire como L1 sem dificuldade qualquer língua em contato com a qual ela cresça. É nesse quadro filosófico que se coloca, portanto, a Gramática Gerativa, e seu projeto de demonstrar que uma única gramática subjaz a todas as línguas do mundo.

Hoje o peso da hipótese inatista é imenso, não somente no âmbito da lingüística teórica e da filosofia da linguagem, mas também na idéia que os estudiosos de outras ciências têm dos resultados da lingüística. Cognitivistas e cultores da Inteligência Artificial, neurologistas, biólogos de todas as escolas e todas as proveniências gostam da idéia de uma capacidade linguiística como módulo built-in no cérebro; isto é, da linguagem não como pura convenção histórica que seja oportuno estudar principalmente com os instrumentos das ciências humanas, mas como produto biológico e, portanto, mais afim aos objetos aos quais eles dedicam normalmente as suas análises. Favorece essa ampla aceitação uma espécie de wishful thinking, em que a preferência para a "manuseabilidade"e afinidade associadas a uma certa hipótese leva a aceitá-la sem dúvidas como a mais fundamentada. De fato, o argumento da Pobreza do estímulo, no qual se baseia toda a tese inatista, geralmente é aceito sem se perguntar adequadamente qual é a sua real consistência. E o que é mais grave, como argumenta minuciosamente Sampson (2005), o argumento foi sempre 
proposto com estupefaciente sumariedade pelos próprios proponentes. ${ }^{8} \mathrm{Em}$ outras palavras, creio justo dar-se conta de que a inteira hipótese inatista, se é verdade que se apóia principalmente sobre o argumento da Pobreza do Estímulo, é o clássico colosso com os pés de argila.

O objetivo deste trabalho é propor algumas evidências a favor da tese de que os pés do colosso são realmente de argila, ou seja, de que as provas e os raciocínios normalmente aduzidos para mostrar que o estímulo é pobre não resistem a uma análise responsável intelectualmente. Faremos, portanto, uma argumentação crítica, que enfrentará quase exclusivamente a pars destruens de um processo de reinterpretação da linguagem em chave não inatista. O que faremos será "desmontar" um certo número de argumentos tradicionais da tese inatista.

A pars construens, de importância ainda maior, consistiria obviamente em mostrar, com resultados de observações empíricas, como durante o processo de aquisição a linguagem realmente evolui nas crianças segundo uma modalidade que revele a ausência, e não a presença, de estruturas inatas no cérebro. Esse trabalho está em curso, e já ofereceu resultados extremamente satisfatórios, por parte de estudiosos como M. Tomasello, e outros. ${ }^{9}$

As críticas que exporemos pertencem a, pelo menos, sete tipos diferentes. Chamá-los-emos, um pouco impressionisticamente, da seguinte forma, e os trataremos nas seções correspondentes deste artigo: ${ }^{10}$

Argumentos "intuitivos" (§2)

Argumentos "evolucionários" $(\$ 3)$

Argumentos "genéticos" $(\$ 4)$

Argumentos "escolásticos" (\$5)

Argumentos “jurídico-esportivos" (\$6)

Argumentos "lingüísticos" (\$7)

Argumentos "pragmáticos" $(\S 8)$

A natureza de cada tipo de argumento se tornará mais clara ao longo da exposição.

\section{Argumentos "intuitivos"}

Se existe uma GU no cérebro, ela deve por definição ser igual em todas as línguas. Dessa forma, cada língua resulta de dois componentes diferentes: o 
que tem em comum com todas as línguas pode ser inato, enquanto o que é peculiar a ela ou em geral o que a distingue de pelo menos uma outra língua deve ser necessariamente aprendido, ou seja, induzido pelo estímulo.

Isso põe uma primeira dificuldade aos defensores da tese inatista, porque precisam demonstrar que realmente existe uma gramática comum a todas as línguas; e depois de meio século a lingüística gerativa conseguiu nessa direção somente resultados parciais, provisórios e bem distantes de um acordo entre a generalidade dos estudiosos. Mas não nos deteremos aqui sobre esse ponto. Ao contrário, desenvolveremos um outro raciocínio: admitindo e não concedendo que a gramática gerativa seja um retrato passavelmente fiel da GU, quanto e como esse fato torna a $G U$ candidata a funcionar como um eficaz dispositivo para a aquisição da linguagem?

A nossa resposta pode ser somente uma: pouco e mal. De fato, para auxiliar a aquisição de maneira significativa, a GU deveria representar uma cota considerável do que a criança adquire; mas as coisas não estão assim. No Esquema 1 propomos comparar quantitativamente, de maneira totalmente impressionística e intuitiva, os dois componentes de cada língua. Na coluna da esquerda colocamos o que (se concordarmos com a gramática gerativa) é igual em todas as línguas e, portanto, pode ser adquirido com a ajuda da GU; e na coluna da direita o que, sendo diferente em cada língua, deve ser adquirido sem a ajuda da GU.

\section{ESQUEMA 1}

\begin{tabular}{|l|l|l|}
\hline & \multicolumn{1}{|c|}{ Igual em todas as línguas } & \multicolumn{1}{c|}{ Diferente em cada língua } \\
\hline 1 & Os Princípios da Gramática Gerativa & $\begin{array}{l}\text { Os valores assumidos pelos Parâmetros } \\
\text { em cada língua }\end{array}$ \\
\hline 2 & Os Universais Linguiísticos & As construções idiomáticas \\
\hline 3 & & Oléxico!!! \\
\hline
\end{tabular}

Não é fácil atribuir valores quantitativos precisos aos dois componentes, mas muitos concordarão que, se um dos dois tem alguma probabilidade de ocupar mais espaço e de agrupar uma maior quantidade de informação, será sem dúvida a da direita. Em outras palavras, no estágio atual da teoria lingüística, se olharmos para todas as línguas conhecidas, o que em cada uma é diferente de pelo menos uma das outras é largamente excedente em relação ao que é comum a todas. As diferenças superam e muito as semelhanças. Articulamos mais o discurso. 
Não podemos aqui entrar em detalhes quanto ao que a teoria gerativa considera dentro dos limites da Gramática Universal. Precisamos remeter a tratamentos específicos, como o de Cook e Newson (1996), baseado na versão da teoria gerativa que melhor se adapta a representar uma GU e ao mesmo tempo a variação interlingüística: aquela denominada "Princípios e Parâmetros". Segundo essa formulação, muitos traços lingüísticos encontrariam espaço na gramática como Princípios (por exemplo, a Teoria da Ligação, a dos Casos, etc.) ou como Parâmetros variáveis, em relação aos quais cada língua modula a sua peculiaridade sob forma de atribuição de valores precisos. Por exemplo, em todas as línguas existe o princípio segundo o qual a ordem núcleo (head) e modificador observa uma certa coerência, coligando a ordem preferida de Verbo e Objeto, de Nome e Adjetivo, de Nome e Caso genitivo, de oração principal e oração relativa, etc. Mas a ordem não é a mesma em todas as línguas, e isso é expresso na teoria com o nome de "Parâmetro Núcleo (Head Parameter)". Essa diferença na fixação de um parâmetro, interagindo com muitas outras análogas, daria conta da diversidade entre as gramáticas das línguas apesar de uma única GU. E daria conta também da criança, durante a aquisição, ser particularmente pronta em adquirir esse traço da sua língua, porque não precisa induzir do estímulo a existência de uma coerência no princípio de ordenamento dos papéis sintáticos: essa informação é inata no seu cérebro! Seria suficiente que ele induzisse do estímulo o valor sobre o qual deve ser fixado o parâmetro, na sua língua específica. Portanto, na linha 1 do Esquema, à esquerda, temos um certo número de Princípios; à direita, os valores que adquirem os vários Parâmetros em cada língua.

Na linha 2, como componente potencialmente inato, temos o conjunto dos universais lingüísticos. Se eles fossem guiados por estruturas inatas no cérebro, poderiam participar do que ajuda a aquisição. Mas é certo e foi muitas vezes argumentado que muitos universais (se não todos) possuem explicações diferentes, de natureza essencialmente pragmática (cf. HAWKINS, 1988; LOMBARDI VALLAURI, 1999), ou até histórica, como veremos na terceira seção. Ao contrário, são diferentes em cada língua as construções idiomáticas (hoje cada dia mais objeto de estudo por parte dos lingüistas que praticam de várias posições alguma versão da Gramática de Construções), que não devem ser confundidas com os diferentes valores paramétricos que adquirem nas várias línguas os princípios da GU, dos quais já falamos e que são mencionados na linha 1 do Esquema. 
Por fim, mas de grande importância, vem o léxico, que é completamente diferente de língua para língua e que representa a massa maior de informação a ser adquirida quando se "conquista" uma língua.

Assim, mesmo com sua inevitável aproximação, o Esquema parece sugerir que, se existisse uma GU no cérebro, ela seria uma parcela pequena em relação a tudo o que compõe uma língua, e então muito pouco poderia fazer para ajudar a aquisição. Mesmo se quisermos acreditar que a linguagem seja adquirida em regime de pobreza de estímulo, disso não deriva de modo algum a necessidade de uma GU inata para explicar o fenômeno; porque a GU, não podendo ir além do que é comum a todas as línguas, seria de utilidade modesta na aquisição de qualquer língua.

\section{Argumentos "evolucionários"}

\subsection{Monogênese}

Se a faculdade da linguagem se baseia na existência de uma GU inata, todos nós devemos descender de um único indivíduo, em cujo cérebro uma série feliz de mutações genéticas acabou gerando essa gramática. A descendência de todos os outros "proto-humanos" se extinguiu sem deixar vestígios.

Não examinaremos aqui a credibilidade desse cenário no quadro evolucionário, já que podem melhor se ocupar disso outros estudiosos. ${ }^{11}$ Mas nos é interessante desenvolver um raciocínio, partindo de uma idéia expressa já por Putnam (1967). O raciocínio é o seguinte. Postular uma GU inata significa fornecer um argumento forte em favor da monogênese das línguas, ou seja, achar que, muito provavelmente, todas as línguas do mundo se originem de uma única língua, aquela desenvolvida pela população do progenitor/progenitora geneticamente com mais sorte. De fato, a hipótese monogenética, que não recebeu muita consideração desde quando Alfredo Trombetti tentou defendê-la, ${ }^{12}$ hoje goza de uma aceitação muito extensa, também graças aos estudos de Luca Cavalli Sforza e colaboradores (1994), aos quais me remeto, sobre as origens geográficas e as migrações pré-históricas dos grupos humanos.

Pois bem, os defensores da GU inata não o perceberam, mas a hipótese da monogênese "retroage" sobre a própria teoria, infligindo um golpe muito duro à sua tese. De fato, um dos argumentos mais fortes em favor da GU é que se não se consegue dar uma explicação pragmática para todos os universais lingüísticos, a melhor explicação possível para a presença de um "núcleo duro" 
remanescente de universais lingüísticos aparentemente arbitrários será a hipótese de que existem no cérebro algumas estruturas às quais todas as línguas devem obedecer. Mas, se admitimos que todas as línguas continuam uma única protolíngua, os universais sem explicação pragmática podem ser devidos a ela, exatamente como muitas das semelhanças entre as línguas neolatinas são devidas simplesmente à descendência comum do latim. Essa será, portanto, a explicação mais econômica, e virá antes daquela inatista, que é mais onerosa porque postula, praeter necessitatem, a existência de uma entidade ad hoc como a gramática inata.

Com uma interessante ação circular, dessa forma a teoria da GU leva à hipótese da monogênese das línguas, e assim perde a possibilidade de ser sustentada pela presença de universais lingüísticos arbitrários.

\subsection{O que plasmou seletivamente o cérebro?}

A hipótese inatista também é vítima de um outro esquema invalidante semelhante ao anterior. ${ }^{13}$ Segundo o modelo evolucionário, as mutações genéticas são casuais, mas a sua afirmação por seleção natural responde a critérios de eficiência. A seleção leva à afirmação das mutações que apresentam vantagens para a sobrevivência, porque os indivíduos que as carregam se reproduzem e sobrevivem melhor, com prejuízo dos outros.

Assim sendo, se existe uma GU inata, deve ter-se afirmado porque os indivíduos que a carregavam tinham uma vantagem em relação aos que não a carregavam. Os portadores de nenhuma gramática, mas também os dotados de gramáticas diferentes, frutos de outras mutações, teriam desaparecido enquanto menos avantajados. Qual poderia ser a vantagem da GU que se impôs? Naturalmente o fato que especificava uma linguagem mais apta a ser usada pelos humanos, ou seja, uma linguagem que respondia melhor a princípios pragmáticos. Em outras palavras, os Princípios da suposta GU e mais em geral os universais lingüísticos seriam exatamente os que observamos, e não outros, porque contribuem para determinar uma linguagem mais apta ao uso, isto é, não poderiam não ser pragmaticamente motivados, porque, em caso contrário, a seleção natural teria selecionado outros melhores. ${ }^{14}$

Assim, somos obrigados a pensar que o Princípio da Dependência da Estrutura, a coerência do parâmetro Núcleo-Modificador, a presença de meios para exprimir o papel de Sujeito e para diferenciar a informação Nova daquela 
Dada, e muitas características comuns a todas as línguas e codificadas pela GU se afirmaram por mutação no módulo cerebral dedicado à linguagem enquanto pragmaticamente ótimas. ${ }^{15}$ Mas então, se elas são pragmaticamente ótimas, sua presença em todas as línguas se explica também sem recorrência à hipótese inatista. De fato, a otimalidade pragmática deve operar em todo caso sobre todos os falantes de todas as línguas, fazendo com que eles adotem, no evento histórico das línguas, aquelas características que funcionam melhor, descartando as outras.

Em outras palavras: se reconhecemos que um traço lingüístico inato, por ter se tornado tal, deve ser ótimo pragmaticamente, dessa otimalidade pragmática temos também uma razão suficiente para explicar a sua difusão universal nas línguas, sem necessidade alguma de imaginar a sua presença no cérebro ao nascimento, que é hipótese mais onerosa e mais rica de postulados ad hoc. Enfim, a preferibilidade pragmática dos universais e das regras gramaticais comuns a todas as línguas permite explicar sua presença diretamente, sem precisar chamar em causa uma GU inata.

\section{Argumentos "genéticos"}

\subsection{Déficit específico}

Já Lieberman (1991, p. 132) avisa que se a linguagem dependesse de um módulo cerebral/mental dedicado especificamente a ela, deveríamos esperar casos de indivíduos com um specific impairment, ou seja, com um déficit lingüístico limitado especificamente a alguns aspectos da GU. Por exemplo, assim como há pessoas que não distinguem as cores, deveria haver pessoas que não conseguem aplicar o Parâmetro Núcleo, ou pessoas que aplicam erroneamente a construção passiva também aos verbos que não designam um caso Objeto. De fato, se essas funções são desenvolvidas pelo cérebro mediante suas habilidades gerais de resolução de problemas, não há razão para que danos anatômicos ou fisiológicos as toquem especificamente; mas supondo-se que existam módulos dedicados a elas e somente a elas, o dano físico a esses módulos deveria se repercutir somente nas regras da gramática.

Depois de um quarto de século, apesar de um grande empenho por parte dos defensores da tese inatista, não existem provas claras da existência de specific language impairment. As afasias afetam sempre aspectos muito gerais da linguagem e comuns a outros âmbitos da ação mental, ligados à capacidade 
mnemônica, à lentidão de processamento, à dificuldade de reconhecer sequiências curtas demais, coisas, enfim, que não apresentam uma natureza especificamente gramatical. Não podemos resumir a grande quantidade de estudos sobre o assunto, mas o estado da arte, longe de ser satisfatório para a posição inatista, pode resultar claro com a leitura de estudos (aos quais simplesmente remeto o leitor) como Ullman-Pierpont (2005), que propõe uma explicação mais plausível para uma série de fenômenos que foram chamados em causa como casos de déficit especificamente lingüístico; ou Cimatti (2007), que leva em consideração e confuta o caso do suposto gene "dedicado à linguagem humana" FoXP2.

\subsection{Variabilidade genética}

Também esse argumento remonta pelo menos a Lieberman (1991, p. 130131), que já sinaliza claramente a implausibilidade de atribuir natureza genética a uma característica humana que não admite variações. Achar que o que é determinado geneticamente deva ser igual em todos os indivíduos é ingenuidade excessiva. Na realidade, se a GU faz parte da bagagem genética, deveríamos esperar que, pelas inevitáveis mutações que acontecem sempre durante a história evolucionária, existissem mais versões, ligeiramente diferentes, da Gramática, e assim indivíduos obrigados geneticamente a seguir regras sintáticas diferentes das dos outros.

Por que, ao contrário, nunca observamos até agora diferentes versões da GU com base individual? Moro (2002), de uma posição favorável à tese inatista, com absoluta honestidade intelectual, anuncia uma tarefa ineludível para considerar a linguagem como um fenômeno programado geneticamente: é preciso demonstrar que entre as gramáticas dos indivíduos existam diferenças dicotômicas e sistemáticas, que mostrem uma distribuição estatística com base familiar igual àquela dos fenômenos bona fide genéticos. E cita Medawar (1983):

One of the gravest and most widespread aberrations of geneticism is embodied in the belief that if any characteristic is enjoyed by all individuals of the community, it must be genetically underwritten. Thus, if it should turn out that a certain basic linguistic form such as the Aristotelian subject/predicate form is an element of all languages of the world, then its usage must be genetically programmed. (...) It may be well to repeat in this context the reason why this supreme 
canon of geneticism is not satisfactory: if any trait is to be judged "inborn" or genetically programmed, then there must be some people who lack it. The ability to taste phenylthiocarbamide, for instance, is known to be genetically programmed because there are those who lack it. ${ }^{16}$

Pois bem, apesar da segurança com que outros estudiosos mais aproximativos (a partir de Chomsky e Pinker) proclamam, ou mais freqüentemente até pressupõem para depois construir ulteriores considerações, a natureza inata da gramática, essa tarefa deve ainda ser desempenhada.

\section{Argumentos "escolásticos"}

Um dos cavalos de batalha da tese inatista se fundamenta na maravilha "do senso comum", algo muito difuso, devido à velocidade e naturalidade com as quais as crianças adquirem suas línguas maternas. É sempre dado como óbvio que a criança seja extraordinariamente rápida e eficiente, se comparada, por exemplo, às dificuldades na aquisição das segundas línguas nas idades sucessivas. Para explicar essa diferença, é possível chamar em causa a diferente "plasticidade" do cérebro nos primeiros anos de vida, que não é relativa somente à linguagem; mas a tese inatista prefere ver nisso um fato especificamente lingüístico, ou seja, o processo de fixação mental/cerebral dos Parâmetros nos valores da L1. Uma vez fixados, os Parâmetros permaneceriam aqueles, e qualquer outra aprendizagem lingüística seguiria caminhos diferentes e menos naturais.

Naturalmente, se as crianças precisassem de muito menos tempo para adquirir a L1, o discurso inteiro cairia: para explicar uma aprendizagem em tempos parecidos com aqueles de aluno de segundo grau que entra em contato com uma língua estrangeira, não é necessário invocar mecanismos inatos de fixação de parâmetros lingüísticos; ao contrário, a teoria inatista defende expressamente que aprendizagens desse tipo acontecem sem a participação da fixação de parâmetros inatos. Já que os defensores da tese inatista dão como óbvio que a aquisição por parte da criança seja maravilhosamente rápida, e nunca param para argumentar esse ponto detalhadamente, tentaremos fazer alguns cálculos do tempo à disposição de uma criança em fase de aquisição de L1 e de um aluno que aprende uma língua estrangeira no segundo grau. 
Antes é oportuno examinar, mesmo se de um modo grosseiro, a competência lingüística que nossos dois "concorrentes" alcançam. No Esquema 2 comparamos os conhecimentos da língua estrangeira por parte de um aluno que a tenha estudado por cinco anos na escola ${ }^{17}$ e aquele da sua própria língua materna por parte de uma criança de três anos.

\section{ESQUEMA 2}

\begin{tabular}{|l|l|l|}
\hline & Aluno de segundo grau (L2 em 5 anos) & Criança (L1 em 3 anos) \\
\hline Fonologia & defeituosa (interferência...) & perfeita \\
\hline Léxico & amplo com lacunas & restrito \\
\hline Morfologia & erros "mnemônicos" e "analógicos" & poucos erros, "analógicos" \\
\hline Sintaxe & $\begin{array}{l}\text { elaborada, com erros "mnemônicos" } \\
\text { e "analógicos" }\end{array}$ & $\begin{array}{l}\text { simples, com poucos erros, } \\
\text { "analógicos" }\end{array}$ \\
\hline
\end{tabular}

A pronúncia da criança é normalmente quase perfeita, enquanto a do aluno deixa a desejar, para dizer a verdade, principalmente onde aparece a interferência dos sons da sua L1. O léxico do aluno, mesmo lhe faltando palavras de uso muito comum, é, contudo, mais extenso do que aquele da criança de três anos, graças ao fato de se "apoiar" naquele da sua L1 que já se tornou amplo. A criança comete menos erros morfológicos, geralmente devido a analogias e hipercorreções. No mais, o aluno comete alguns erros devido à ainda imperfeita memorização das formas da língua estrangeira. A sintaxe da criança é um pouco mais correta, mas também mais simples, porque a do aluno pode se apoiar no hábito de produzir enunciados sintaticamente complexos na própria L1. Enfim, provavelmente é possível reconhecer uma certa vantagem para a criança, principalmente quanto à naturalidade com que usa a sua língua. Mas quanto tempo os dois foram expostos à língua em questão?

A resposta a essa pergunta está no Esquema 3: 
ESQUEMA 3

\begin{tabular}{|l|c|c|}
\hline & Aluno de segundo grau (L2 em 5 anos) & Criança (L1 em 3 anos) \\
\hline Tempo & $2 \mathrm{~h} \times 30$ semanas x 5 anos $=300 \mathrm{~h}$ & $12 \mathrm{~h} \times 365$ dias $\times 3$ anos $=13.000 \mathrm{~h}$ \\
\hline $\begin{array}{l}\text { Qualidade } \\
\text { da fonte }\end{array}$ & modesta & perfeita \\
\hline Motivação & baixa & altíssima \\
\hline
\end{tabular}

Calculando as três horas semanais de língua estrangeira e o número de semanas na escola, vê-se que o aluno depois de cinco anos foi exposto a cerca de 300 horas de língua estrangeira. Depois de três anos de vida e 12 horas por dia, a criança, ao contrário, totalizou 13.000 horas de exposição à sua língua materna. Em outras palavras, como tempo de exposição ao estímulo lingüístico,

5 anos de segundo grau $=25$ dias de infância

$\mathrm{e}$

3 anos de infância $=220$ anos de segundo grau

A essa diferença temos que acrescentar o fato de que o input à disposição do aluno é freqüentemente imperfeito (professores de língua não materna...), e que a motivação do aluno é geralmente pouca ou nula, enquanto evidentemente a criança coloca todo o seu empenho.

Talvez nosso raciocínio contenha alguma imperfeição e precise ser aperfeiçoado, mas não há dúvida de que esse tipo de atenção faltou completamente nos fatores do Argumento da Pobreza do Estímulo, cuja sumariedade exagera em dar por pressuposto que a aquisição por parte da criança seja um processo surpreendentemente rápido e, portanto, inexplicável sem postular gramáticas residentes no cérebro.

\section{Argumentos "jurídico-esportivos"}

Em uma perspectiva inatista, o fato de que as produções lingüísticas respeitem as regras de gramática, pelo menos aquelas consideradas universais, é visto como efeito da presença dessa gramática no cérebro. Contudo, pode-se observar que os humanos são vinculados ao respeito às regras de gramática de maneira totalmente diferente de como são vinculados aos comportamentos 
determinados biologicamente. Vejam-se, por exemplo, os enunciados inaceitáveis em (1-4):

(1) Rome my brothers has gone

(2) tempo é eu partir

(3) Komme zu dich schnell

(4) Mange et arrive

Qualquer um, se quiser, pode produzir enunciados desse tipo, e também decodificá-los, ou seja, atribuir um provável sentido a eles, mesmo reconhecendo a agramaticalidade. Nosso cérebro não tem dificuldade alguma em fazer isso. Isto também vale para enunciados como (5), que é citado por Chomsky como exemplo de violação de um dos princípios fundamentais da GU, o Princípio da Dependência da Estrutura; e para (6), que viola o mesmo Princípio, como veremos na seção 7.3.:

(5) *Is the man who tall is in the room?

(6) *does the man who own a dog sleeps in the room?

Contrariamente à obediência à GU, os comportamentos guiados por estruturas biológicas inatas acontecem de modo inderrogável. Por exemplo, nosso sistema nervoso não pode não inverter a imagem que se forma na retina durante o processo da visão, nem evitar ordenar a secreção da adrenalina no caso de perigo. Nós não obedecemos sempre a essas "regras de funcionamento" do nosso organismo simplesmente porque é conveniente, mas sim porque somos impossibilitados de fazer de outra maneira.

As regras da gramática, ao contrário, assemelham-se às leis do Estado, ou às regras do basquete: nós poderíamos perfeitamente violá-las, mas geralmente as respeitamos porque é mais conveniente. Arazão pela qual é mais conveniente é que fazemos parte de uma coletividade que as observa, e violando-as nos colocaríamos em alguma medida fora dela, com algum prejuízo da nossa possibilidade de convivência pacífica (caso se trate das leis do Estado), de jogar (caso se trata do basquete), de comunicar (caso se trata da gramática).

Enfim, as regras da gramática (universal ou não, aqui não faz diferença) vinculam as coletividades que querem interagir, mas não os indivíduos em si. Ao contrário, o que é genético se manifesta diretamente no indivíduo. Se queremos 
dizer que a gramática é, para cada um de nós, inviolável tanto quanto a inversão da imagem na retina, podemos (no máximo) dizê-lo para a coletividade que a adota, mas não para o indivíduo. O inatismo lingüístico mantém sua credibilidade somente se se confunde, de um modo, para dizer a verdade, um tanto quanto grosseiro, o plano individual com o coletivo.

\section{Argumentos lingüísticos}

Com relação a várias das perspectivas das quais é possível olhar para a questão do inatismo lingüístico, tentamos demonstrar que as "posições" inatistas são freqüentemente pouco mais que declarações genéricas de aparente bom senso, mas incapazes de resistir a modestos controles no mérito. Contudo, o ponto forte da tese inatista, pelo menos do ponto de vista de um lingüista, consiste nos argumentos especificamente lingüísticos. Tanto Chomsky quanto seus seguidores formulam exemplos de comportamentos lingüísticos que crianças e adultos adotam de modo generalizado, e afirmam que o estímulo não é suficiente para explicar sua aquisição. Em outras palavras, existiriam conhecimentos lingüísticos aos quais não seria possível chegar graças à experiência, e isso só, se fosse verdade, bastaria para demonstrar que esses conhecimentos lingüísticos devem residir no cérebro.

Pois bem, todos os exemplos que, pelo que eu sei, foram fornecidos afirmando que implicam um saber não disponível para os falantes mediante a experiência são facilmente confutáveis: é sempre fácil mostrar que a experiência da língua à qual somos expostos e do mundo em que a usamos fornece todos os instrumentos necessários para que os falantes aprendam tudo que serve para justificar seus comportamentos lingüísticos, sem precisar inventar módulos gramaticais inatos no cérebro. Todos os exemplos apresentados na literatura como comportamentos que não seriam induzíveis pelo estímulo são induzíveis pelo estímulo. Aqui poderemos olhar só para alguns, escolhidos enquanto típicos de algumas falácias recorrentes no raciocínio inatista, e em todo caso porque se tornaram "clássicos" e propostos com mais autoridade.

\subsection{Ordem básica}

Uma falácia freqüente nas argumentações de cunho inatista é raciocinar como se a língua fosse aprendida isolada da realidade. Freqüentemente, todo o raciocínio é conduzido como se a língua se reduzisse à sintaxe, e como se essa 
não interagisse com a semântica e, portanto, com o contexto em que os enunciados são de fato produzidos.

Por exemplo, Morgan (1986) propõe uma "prova" da presença de informações lingüísticas inatas no cérebro, que foi acolhida no manual de Cook e Newson (1996). A prova seria a seguinte. Sentenças como

(7) O cachorro morde o gato.

não ajudariam a criança a saber se a língua é SVO o OVS. Essa informação estaria à disposição da criança somente se enunciados desse tipo fossem apresentado com alguma forma de "parentetização" do SV, como em:

(8) O cachorro [morde o gato].

Por isso, Morgan enfatiza a importância de pausas e acentos, que têm a função de indicar as fronteiras sintáticas. Isso tudo, como se a experiência da criança não fosse constantemente acompanhada por enunciados do tipo $o$ professor pune o aluno ou a mamãe prepara a sopa, que são sintaticamente equivalentes a (1), mas, por óbvias razões semânticas e de conhecimento da realidade permitem induzir que o sujeito é o elemento que antecede o verbo.

\subsection{Ambiguidade sintática}

Hoekstra e Kooij (1988) propõem um raciocínio baseado nos enunciados seguintes: ${ }^{18}$

(9) a. Where did John say that we had to get off the bus?

b. Where did John ask whether we had to get off the bus?

Both sentences are grammatical. However, while (2a) is ambiguous between a reading in which where has matrix scope and a reading in which it has embedded scope, (2b) can only be interpreted as a question concerning the place where John uttered a particular question (that is, with matrix scope). This piece of knowledge is shared by all native speakers, but it can hardly have been established on the basis of induction, simply because there are no data from which induction could conceivably proceed. (...) The reasonable assumption seems to be that the child, on the basis of whatever 
relevant data he or she encounters, must try to find an answer to the question why there is no embedded scope for where in (2b), and, more generally, must try to find out which conditions are 'barriers' for the extraction of question words. Data like (2a) and (2b), no matter how carefully 'stored', are in themselves largely insufficient to provide an answer to these questions unless the child also has access to complex principles of UG that determine the (im)possibility of extraction in otherwise similar configurations.

What we are confronting then is a system which is constant through the species and which has the properties that are underdetermined by the environment. These are precisely the characteristics that lead to the postulation of a property of the genotype. (...) In the case of language, a distinction is made between a core grammar of each individual language which is determined by the genotype, and a language specific periphery which accounts for the variation across languages. ${ }^{19}$

Os autores concluem que, sendo subdeterminada pelo input, a cognição da diferença sintática entre os dois exemplos deve ser determinada geneticamente.

Aplicaremos a nossa crítica aos equivalentes portugueses dos exemplos que acabamos de citar:

(10) Aonde Carlos disse que devíamos descer do ônibus?

(11) Aonde Carlos perguntou se devíamos descer do ônibus?

Como observam justamente Hoekstra e Kooij, cada falante percebe que (10) é ambígua, enquanto (11) não, no sentido que em (10) o advérbio interrogativo aonde pode pertencer à principal ou à subordinada, enquanto em (11) ele pertence somente à principal. Conseqüentemente, em (10) a pergunta pode verter sobre o lugar aonde Carlos falou para dizer que precisava descer, ou sobre o lugar aonde, segundo Carlos, era preciso descer. Ao invés, em (11) a pergunta verte unicamente sobre o lugar aonde Carlos falou. Segundo os nossos autores, a noção desses fatos não é acessível aos falantes por indução. Conseqüentemente, deve existir no cérebro uma informação inata, evidentemente de natureza estritamente lingüística, ou seja, sintática, que permite a todos os falantes que reconheçam a diferença entre esses enunciados. 
Se se consideram os enunciados em questão de um ponto de vista puramente sintático, poder-se-ia até concordar, porque os contextos de uso não fornecem informação sintática para enunciados assim. Mas isso, em primeiro lugar, é quase tautológico (os contextos de uso, por sua própria natureza, não fornecem nenhuma informação sintática, porque são situações reais e não gramáticas descritivas); em segundo lugar, é uma maneira sem dúvida parcial de considerar os fatores em jogo. De fato, não é dito que a informação que permite aos falantes apreciar a diferença entre os dois exemplos seja de natureza sintática. Essa crença é só o fruto da importância excessiva atribuída à sintaxe nas abordagens gerativistas. Se apenas levamos um pouco em conta a semântica e a realidade extralingüística a que a semântica dos enunciados faz referência, vê-se que nelas há a razão pela qual ao falante/aprendiz resulta claro que (10) pode ser ambígua e (11) não. A diferença está nos diversos sentidos dos verbos dizer e perguntar e, portanto, na sua adaptabilidade a diferentes estados de coisas. As duas interpretações em (10) poderiam ser parafraseadas assim:

(10a) Aonde Carlos falou, pra dizer que precisamos descer?

(10b) De acordo com o que Carlos disse, aonde precisamos descer?

Ambas as alternativas fazem sentido. Não podemos dizer o mesmo das duas correspondentes interpretações de (11):

(11a) Aonde Carlos falou, para perguntar se precisamos descer?

(11b) *De acordo com o que Carlos perguntou, aonde precisamos descer?

Isso porque o verbo perguntar, não possuindo o sentido de "asserir", não pode significar um ato de palavra do qual derive informação (em modalidade assertiva) sobre aonde é preciso descer. Dessa forma, é possível perguntar-se aonde Carlos tenha feito uma pergunta, mas não quais fossem as instruções sobre aonde descer contidas na pergunta de Carlos, exatamente porque uma pergunta, pela própria definição da sua ilocutividade, não contém instruções. É esse estado de coisas que faz com que (11) tenha uma única interpretação; depois, é o conhecimento de mundo, e em particular a diferença entre uma pergunta e uma asserção, que faz com que os falantes não levem em consideração o outro sentido "sintaticamente possível" de (11). Realmente não precisam imaginar que, ao contrário, o cérebro hospede um módulo gramatical anterior a toda experiência, para que a interpretação (b) seja excluída. 


\subsection{Dependência da estrutura: a pergunta em inglês}

Crain e Nakayama (1987) propõem uma argumentação que teve grande fortuna na literatura inatista, e que, com efeito, é retomada tanto por Cook e Newson (1996), quanto por Akmajian et al. (1984). ${ }^{20}$ Provavelmente ela deve parte da sua popularidade ao fato de que se refere a um dos princípios centrais da suposta GU: o da Dependência da Estrutura. Esse princípio consiste na observação, empiricamente mais que demonstrada, de que no funcionamento das línguas um papel importante é exercido pela estrutura, e não só pela ordem seqüencial dos elementos. Até aqui nós também concordamos. Mas outra coisa é afirmar, como a literatura de cunho inatista afirma, que esse fato não pode ser aprendido, e deve ser, em princípio, inato.

Por exemplo, observam Crain e Nakayama que, em inglês, a versão interrogativa de (12) é (13), que se obtém movendo o verbo para o início:

(12) The man is tall.

(13) Is the man tall?

A criança que adquire a língua poderia deduzir disso que a versão interrogativa de (14) seja (15), correspondente a uma instrução do tipo: procura um verbo, e quando o acha, traga-o para a extrema esquerda:

(14) The man who is tall is in the room.

(15) *Is the man who tall is in the room?

Assim fazendo, a criança demonstraria que é sensível a questões de ordem dos constituintes (pega o primeiro verbo), mas não de estrutura (pega o primeiro verbo com papel de regente), e então que não leva em conta a hierarquia sintática com base na qual a relativa é subordinada à principal, e coisas do tipo. Mas na realidade:

children do not produce questions like the ill-formed (15). Therefore, it appears that children know that structure, and not just the more salient linear order property of sentences, is relevant in the formation of yes/no questions. ${ }^{21}$

Segundo os autores citados, isso não pode depender de nenhuma informação disponível às crianças durante a aquisição, porque ninguém diz nunca 
a elas explicitamente que não é a ordem seqüencial, mas é, ao contrário, a estrutura, que determina a aplicação da regra e, portanto, o princípio da Dependência da Estrutura deve preexistir no cérebro.

Para construir a interrogativa correta:

(16) Is the man who is tall in the room?

qualquer falante deve saber que (11) não é uma simples lista de palavras, mas um conjunto estruturado. E em particular deve saber que who is tall entra nessa estrutura como um elemento em certa medida separado do resto, mesmo se dependente dele. Com isso é difícil não concordar; mas não me parece necessário pensar que essa noção seja inata. A fala à qual a criança é exposta apresenta em abundância exemplos de dependência da estrutura e, em particular, aqueles que podemos chamar de "provas de comutação", como:

(17) - Gosto dos homens com muitos músculos.

- Quais homens?

- Aqueles que têm muitos músculos.

Trocas como (11) permitem compreender que a relativa, "a coisa introduzida por que" (ingl. who) constitui uma unidade. Além disso, as crianças anglófonas ou lusófonas são expostas a milhares de ocorrências do pronome relativo, nunca seguido por um adjetivo. Depois do relativo há sempre o verbo (ou um nome sujeito, se o relativo não é sujeito). Portanto, não precisa haver uma noção inata, para entender que who tall em (15) é inaceitável. ${ }^{22}$

Ainda mais importante é a consideração seguinte: como nos exemplos que vimos nas seções anteriores, aqui também os inatistas subestimam o papel da semântica. O significado dos enunciados pode muito bem levar à compreensão de que a função das orações relativas é especificar ou restringir o significado do núcleo, enquanto a predicação principal é devida à principal. Portanto, para quem já foi exposto a um certo número de construções relativas, é fácil entender que a interrogativa deve ser feita sem tocar a relativa. Isso porque o que se quer submeter à interrogação não é o conteúdo expresso pelo verbo da relativa, mas o conteúdo expresso pelo verbo da principal. Realmente, no estímulo ao qual a criança anglófona é exposta, todas as perguntas que contêm uma relativa são perguntas em que a relativa permanece intacta e a inversão (ou a construção com do/does) acontece sobre a principal. Isso não é claramente visível no 
exemplo de Crain e Nakayama, por causa da escolha um tanto quanto seletiva de usar em ambas as orações o verbo is. Mas em orações principal-relativa em que os dois verbos são diferentes, existiriam elementos claros para prevenir o aprendiz do erro. A pergunta formada a partir do tipo:

(18) The woman who makes ikebana lives with a cat.

Não é nunca do tipo:

(19) *does the woman who make ikebana lives with a cat?

Mas sim sempre do tipo:

(20) does the woman who makes ikebana live with a cat?

Poder-se-ia objetar que aqui nenhum dos dois verbos admite a inversão, e, portanto, o exemplo (19), não prevendo deslocamento de verbos, não é significativo porque não ajuda um comportamento por analogia, no caso de necessidade de se fazer uma interrogação com o enunciado (14). Vejamos então um caso em que o verbo da relativa admite a inversão e o outro não, encorajando assim o erro visto em (15):

(21) The man who is tall eats popcorn.

Se se aplicasse a "regra" que prescinde da estrutura, levando em primeira posição o verbo, teríamos:

(22) *is the man who tall eats popcorn?

Esse erro é excluído simplesmente porque nenhuma criança tem motivo de pensar que, colocando em primeira posição o verbo $i s$, seja interrogado o conteúdo do verbo eats. A regra que a criança segue é, portanto, esta: quando o verbo permite, coloque-o em primeira posição se quiser submeter à interrogação SEU conteúdo. Para chegar a isso, obviamente, pode ser ajudada pelo fato de que a interrogação de enunciados como

(23) The girl who drank the wine is from China.

é

(24) Is the girl who drank the wine from China? 
Aonde se vê que, para tornar interrogativa a principal, é preciso deslocar seu verbo para a primeira posição, e não o verbo da relativa. Acontece então o mesmo que com outras funções lingüísticas: só para dar um exemplo, com a negação, em que para negar o verbo de uma oração se coloca em forma negativa esse mesmo verbo, e não aquele de outra oração:

(25) I don't eat tuna that contains dolphin.

(26) I eat tuna that doesn't contain dolphin.

Como é óbvio, tanto em (25) quanto em (26) é negado o conteúdo do verbo em forma negativa, e não o conteúdo do verbo que permanece em forma positiva: esse tipo de informações, perfeitamente acessíveis a quem adquire a linguagem, torna fácil reparar o fato mais geral de que a modificação formal de um elemento lingüístico determina uma modificação semântica daquele mesmo elemento, e não de outros.

Enfim, em primeiro lugar, é provável que as crianças, se devem mesmo realizar a versão interrogativa de um enunciado que contém uma relativa, se inspirem nos exemplos de enunciados que contêm uma relativa (como 23-24), e não nos exemplos de enunciados que não a contêm (como 12-13). Além disso, nesses enunciados não acontece nunca que o verbo deslocado no começo (ou interrogado mediante do/does) seja aquele da relativa. É graças a essa experiência que as crianças respeitam a relativa. Podemos até chamar isso de princípio da dependência da estrutura, mas não há motivo de presumir seu caráter inato, já que a informação para sua aquisição é tão disponível no estímulo.

É preciso observar também que, inata ou não, a noção de uma dependência de muitos elementos na realidade de uma estrutura não é mesmo, no homem, uma dotação limitada ao domínio lingüístico. A realidade contém muitos tipos de objetos complexos, seja materiais, seja abstratos, e nós os concebemos sistematicamente como organizados por vínculos e relações que observamos entre eles. Por exemplo, preparando a mesa, não tratamos as louças uma por vez e na ordem na qual elas se sucedem no espaço: se é necessário deslocar uma pessoa, deslocamos tudo que está no seu lugar da mesa, que para nós é, dentro da mesa preparada, uma subparte por sua vez complexa e estruturada internamente. ${ }^{23}$ Olhando para uma bicicleta totalmente desmontada (como às vezes acontece de se ver nas publicações especializadas) com todas as peças colocadas no chão, 
percebemos imediatamente que se trata de algo diferente de uma bicicleta "inteira", em que o conjunto montado respeita a estrutura correta. Obviamente quem constrói bicicletas faz isso de maneira dependente da estrutura, e todos nós distinguimos uma bicicleta em condições de funcionar (ou seja, dotada de estrutura) de uma em que as peças sejam juntadas ao acaso. Quando lemos o horário dos trens, para sabermos a hora em que chega na nossa estação o trem das 17, olhamos a coluna e a linha correspondentes àquele trem e àquele destino, cientes do fato de que o horário é um conjunto estruturado coerentemente e não uma lista de dados em mera seqüência.

Enfim, somos animais capazes de reconhecer a presença de estruturas, onde quer que se encontrem, e não somente na linguagem. Se então se trata de uma dotação genética da nossa espécie, ela deve ser vista como parte daquelas capacidades gerais de categorização e solução de problemas mediante as quais, segundo quem não acredita na GU, é gerenciada também, mas não somente, a linguagem.

\subsection{Línguas Pro-drop (e a informação negativa)}

Característica da tradição inatista é a subestimação da assim chamada "informação negativa", ou seja, a idéia de que a criança possa adquirir as regras da língua somente através de sinais explícitos, e de que a ausência de um fenômeno no estímulo não possa nunca ser suficiente para deduzir que aquele fenômeno não faz parte da língua. Ao contrário, é certo que a constante e exclusiva repetição de um padrão pode levar à certeza de que outros padrões devam ser excluídos. ${ }^{24}$

Como se sabe, há línguas em que o sujeito não é obrigatório (ditas prodrop), e línguas em que é obrigatório (ditas non pro-drop). A criança se orienta na língua que adquire com base no que ouve. Cook e Newson citam várias intervenções de Chomsky para defender que a única maneira com que a criança pode compreender como estão as coisas na sua língua é a predisposição paramétrica inata com dois valores: sujeito obrigatório e sujeito não obrigatório. ${ }^{25}$ Hyams (1986) mostra acreditar muito rigidamente nessa condição. Segundo ela, se a criança entende que em inglês o sujeito é obrigatório, isso aconteceria graças à presença de orações com expletivos, como once upon a time there were three bears, ou it's time for bed. Tais exemplos, mostrando a obrigatoriedade do sujeito, fariam desencadear o parâmetro inato. 
Creio que não seja necessário formular uma hipótese desse tipo. Os milhares de sentenças que a criança escuta durante a aquisição de uma língua não pro-drop (por exemplo, o inglês ou o francês), que apresentam sempre o sujeito, são uma razão suficiente para que ele tenda a produzir sempre sentenças com o sujeito. Igualmente, uma criança italiana ou espanhola se dá conta de que não precisa usar sempre o sujeito porque, nos enunciados que compõem seu estímulo, o sujeito não está sempre presente. Não me parece que isso se torne possível somente se existe um parâmetro pré-ajustado no cérebro: pelo fato de que todos os carros que ele vê têm as rodas, a criança é levada a desenhar todos os carros com as rodas; enquanto, pelo fato de que somente algumas casas têm chaminé, ela aprende que pode desenhar casas tanto com ou sem chaminé. Inclusive, a criança italiana ou espanhola aprende (e não pode ter como inata) uma coisa bem mais complexa do que o simples fato de que o sujeito é facultativo, ou seja, aprende quando é preciso torná-lo explícito e quando não, obedecendo a refinados vínculos coligados à anterior instauração do referente no contexto lingüístico e extralingüístico, e à sua própria intenção de dar a ele maior ou menor relevância informacional.

\section{Argumentos "pragmáticos"}

Um forte argumento geral em favor da existência de uma gramática no cérebro poderia ser a existência de invariâncias entre as línguas que não sejam motiváveis de outra forma. Visto que as línguas faladas pela humanidade são milhares, uma característica comum a todas não pode existir por acaso, mas deve necessariamente depender de algo inerente no homem e na sua maneira de se servir da linguagem. Por exemplo, se todas as línguas preferem as vogais orais às nasais, onde estará a razão? Por que não no cérebro que deve comandar os órgãos (o diafragma, a glote, a língua, o véu ...) envolvidos na articulação desses sons? E se todas as línguas possuem uma morfologia que distingue a categoria do Nome daquela do Verbo, não será porque nossa mente não pode evitar conceber a realidade como dividida em Entidades e Processos?

Freqüentemente é possível explicar os universais lingüísticos. ${ }^{26} \mathrm{Se}$ todas as línguas preferem as vogais orais às nasais, a razão é provavelmente que (salvo em proximidade de uma consoante nasal) o esforço muscular necessário para produzir as primeiras é menor do que aquele necessário para as segundas. 
Talvez isso valha também para a quantidade de trabalho que o cérebro deve comandar ao véu para que se abaixe. O cérebro, portanto, pode estar envolvido em determinar esse universal lingüístico, mas nesse caso o que entra em jogo não é uma eventual regra gramatical residente nele, mas sim uma tendência do funcionamento geral que opera em todos os outros campos de ação dos organismos viventes, ou seja, a tendência a usar o mínimo esforço para alcançar o resultado desejado.

Há muitas outras características difusas universalmente entre as línguas às quais é possível dar explicações em termos funcionais. Por exemplo, se todas as línguas utilizam tanto fonemas vocálicos quanto consonânticos, isso é devido ao fato de que pronunciar e ouvir distintamente palavras feitas somente de consoantes seria muito mais difícil do que é com palavras feitas por ambos os gêneros de sons. Palavras que contêm somente vogais não criariam problemas, mas nosso ouvido não pode distinguir bem um número elevado de vogais: o espaço em que são articuladas não hospeda mais que cerca de dez, pois, se duas vogais são articuladas perto demais resultam parecidas demais, e são confundidas. Agora, com somente dez fonemas, é difícil compor o grande número de palavras dos quais uma língua precisa, e que se obtém combinando vogais e consoantes.

Se em todas as línguas existem expressões dêiticas, isso se explica através de uma mais que natural razão de economia. Faltando expressões como isso e aquilo, em vez de poder dizer essa cadeira ou aquela janela, precisaríamos de um nome diferente para cada cadeira e cada janela do mundo. E precisaríamos, também, de lembrar de todos.

Se em cada língua os elementos que exprimem conceitos coligados mentalmente resultam coligados sintaticamente, isso se explica com o esforço muito menor que é imposto ao cérebro em fase de elaboração da mensagem, se os elementos que constituem um enunciado se apresentam agrupados desse jeito. Para processar a avó tem repreendido os netinhos, é suficiente processar primeiro a avó, depois tem repreendido e depois os netinhos, isto é, percorrer o enunciado da esquerda para a direita se se lê, ou escutá-lo na ordem com que é produzido oralmente. Ao contrário, para processar avó tem os repreendido netinhos a, é preciso a partir de avó percorrer todo o enunciado até o final, onde está $a$; depois voltar atrás para processar o verbo, e assim por diante. É o mesmo tipo de diferença que encontramos em entender o que um quebra-cabeça representa, se todas as peças estão no lugar ou se está desmontado. Se essa 
"recomposição mental" parece possível com um enunciado escrito, com a volatilidade da fala seria muito mais difícil.

Se todas as línguas possuem categorias pronominais que implicam pelo menos três pessoas, isso se explica com uma motivação muito evidente e nada "cerebral": na maior parte das situações comunicativas se distinguem os papéis de quem produz a mensagem, de quem é destinatário dela e de quem não é nem uma coisa nem outra.

Examinando-se um universal implicacional: o universal n. 44 de Greenberg (1966): "Se uma língua apresenta distinção de gênero na primeira pessoa, apresenta sempre distinção de gênero na segunda ou na terceira pessoa, ou em ambas" pode-se explicar, pelo menos em parte com a exigência pragmática de tornar a sentença o menos ambígua possível, a referência dos pronomes. A implicação depende do fato de que graças à distinção de gênero fica mais fácil associar os pronomes a um referente em vez de um outro. Por exemplo, se digo:

(27) Carlos e a sua irmã jogam basquete, mas somente ele/ela está num time importante,

a escolha do pronome masculino ou feminino permite esclarecer se o referente é Carlos ou a sua irmã. Em uma língua sem distinção de gênero no pronome, isso não seria possível e a sentença seria ambígua, a não ser que fossem utilizados instrumentos alternativos (por exemplo: ... mas somente o primeiro dos dois está num time importante, etc.)

Isso não serve no caso do pronome de primeira pessoa, cujo referente é em todo caso conhecido e identificável de maneira unívoca com o falante. Portanto, as línguas se dividem entre aquelas que, por razões próprias, preferem não onerar os pronomes pessoais da categoria morfológica de gênero, aquelas que não têm nenhuma dificuldade em fazer isso e assim distinguem o gênero em todas as pessoas e, por último, aquelas que admitem essa categoria nos pronomes, mas tendem a economizá-la e, assim, reservam-na somente às pessoas nas quais é pragmaticamente mais útil, ou seja, a terceira e/ou a segunda.

Uma explicação análoga pode ser dada pelo fato de que em uma língua a distinção entre pronome reflexivo e não reflexivo na primeira pessoa (ex: ingl. me/myself) e na segunda (you/yourself), implica a mesma distinção na terceira. É claro que essas implicações refletem o fato de que a função de desambiguação entre diversos referentes possíveis dos pronomes pessoais cresce das primeiras duas pessoas à terceira. 
Diferentemente do inglês, em alemão o pronome pessoal objeto e o reflexivo são iguais na primeira (mich) e na segunda pessoa (dich). Na terceira pessoa, porém, são diferentes como em inglês (pron. pess. masc. ihn, fem. sie, neutro es; pron refl. masc, fem. e neutro sich).

Apesar da não-gramaticalidade, o exemplo inglês em (28c) não é ambíguo, como não é ambíguo o equivalente alemão em (28b):
(28a) I wash myself.
(eu lavo a mim mesmo)
(28b) Ich wasche mich.
(eu lavo a mim mesmo)
(28c) *I wash me.
(eu lavo mim)

Alguma ambigüidade poderia talvez surgir na segunda pessoa, no caso do alemão (29b), mas somente em presença de pelo menos dois destinatários do enunciado que fossem indicados separadamente. Nesse caso, o inglês utilizaria (29c):

(29a) You wash yourself. (você se lava a si mesmo)

(29b) Du wäschst dich. (você lava você)

(29c) You wash you. (você $\hat{e}_{1}$ lava você $\left.\hat{e}_{2}\right)$

A ambigüidade seria, ao contrário, muito freqüente se o alemão não pudesse dispor dos meios morfológicos para distinguir o simples pronome pessoal do reflexivo para a terceira pessoa, dado que é absolutamente natural um contexto com mais de um "ele" e, portanto, são prováveis tanto a ação reflexiva quanto a transitiva:

\section{REFLEXIVOS}

(30a) He washes himself. (ele lava a si mesmo)

(30b) Er wäscht sich. (ele lava a si mesmo)

\section{PESSOAIS OBJETO}

(30c) He washes him. $\left(\right.$ ele $_{1}$ lava ele ${ }_{2}$ )

(30d) Er wäscht ihn. $\left(\right.$ ele $_{1}$ lava ele ${ }_{2}$ )

As explicações dos universais como aquelas que exemplificamos, em termos de reflexão da ordem da realidade por parte da língua, ou em termos de praticidade/economicidade de processamento da mensagem lingüística, abundam. Naturalmente o cérebro é fortemente envolvido, e essa maneira de funcionar nos confirma que o cérebro é uma "máquina" que precisa de clareza e foge da ambigüidade; ou que, como o corpo todo, trabalha com esforço e, assim, 
tende a preferir estratégias que, com igual resultado, requerem menos tempo e esforço. Nessa ótica, podemos dizer que as causas pelas quais a linguagem é como é residem também no cérebro, mas genericamente e indiretamente. $\mathrm{O}$ cérebro exige clareza (ou seja, não ambigüidade) e economia de esforço, mas "deixa livre" à linguagem alcançar esses resultados dependendo dos vínculos que são impostos em grande parte pela realidade externa. Por exemplo, gera vínculos ao funcionamento da linguagem a forma dos órgãos fonatórios, o fato de que, nas situações comunicativas, os papéis do locutor, do destinatário e de quem não é nem uma coisa nem outra são normalmente distintos, o fato de que existem na realidade muitos objetos fundamentalmente iguais entre eles, de maneira que em vez de dar um nome diferente a todos eles $(X, Y, Z \ldots$...) seja possível "economizar" palavras e designar os objetos através de categorias, identificando-os depois no contexto comunicativo graças aos dêiticos, eventualmente em conjunto com gestos (esse $X$, aquele $X$, aquele outro $X$ ).

A tese inatista, ao contrário, consiste em pensar que o cérebro determina especificamente e diretamente a forma da linguagem, porque não se limita a estabelecer vínculos ou preferências de clareza e economia que reduzem o espaço disponível à variação da linguagem na realidade pragmática das situações comunicativas; mas dita a própria gramática, e não pode evitar ditá-la, porque a contém. Uma explicação completa de todos os componentes da gramática a partir de causas pragmáticas tornaria inútil a tese inatista e provavelmente a demoliria; mas mesmo se as causas de todos os universais gramaticais fossem pragmáticas, não há certeza de que seria possível reconstruir as complexas relações de causa-efeito que vão das exigências pragmáticas às regras gramaticais.

Ater-nos-emos aqui a um problema preliminar: justificar pragmaticamente não a forma que os traços gramaticais comuns a muitas ou a todas as línguas tomam, mas somente a própria existência da gramática em si, isto é, o fato elementar de que cada língua, para funcionar, precisa de uma gramática.

Para explicar a mera existência de uma gramática, não é necessário aduzir uma arquitetura específica no cérebro, mas bastam forças "externas" que vinculam a atividade humana da linguagem.

A primeira dessas forças é a limitação da memória de curto prazo e da potência de elaboração. Por causa disso, para fazer a linguagem funcionar é necessário um conjunto de regras. Não seria conveniente, cada vez que se quer traduzir um pensamento em um enunciado, ter que inventar, instantaneamente, 
essa maneira. Convém ter rotinas nas quais apoiar-se, para funcionar "em automático". A exigência da gramática surge, portanto, já quanto à simples função expressiva e somente interior da linguagem. A gramática serve enquanto estrutura automatizada na qual se confia para não se ter que elaborar a cada vez meios diversos para exprimir o próprio pensamento.

Dessa forma, as razões da criação de regularidades, sejam elas o que forem, são em primeiro lugar de natureza pragmática. A regularidade serve para economizar carga mental durante a programação dos enunciados. Se o falante devesse constantemente, a cada enunciado, decidir ex novo onde colocar cada elemento da sentença e como sinalizar sua função, consumiria muito mais energia e no mínimo deveria falar muito mais lentamente do que faz ao seguir o hábito de respeitar as regras da sua língua.

No entanto, o falante não é a única instância que coloca a exigência de uma gramática. A mesma exigência é colocada pelo receptor que deve interpretar os enunciados lingüísticos. Não bastaria "despejar" no nosso interlocutor um monte de palavras-conceitos das quais subjetivamente sentimos quais são as relações; ao contrário, é necessário fazê-lo de maneira convencionalizada, que permita reconhecer intersubjetivamente quais relações devem entender-se como operantes no enunciado. Portanto, para comunicaremse, deve existir acordo entre emissor e receptor não somente sobre o sentido dos itens lexicais, mas também sobre a interpretação a dar às relações entre eles, e assim praticamente a um conjunto de sinais gramaticais.

Enfim, a presença de regras da gramática (morfologia e sintaxe) é devida à função de compartilhar a linguagem, na codificação e na decodificação. A linguagem é uma atividade intersubjetiva, que pressupõe, para funcionar, o acordo de mais sujeitos sobre as modalidades de seu funcionamento. Se esse acordo faltasse, a linguagem não funcionaria mais, exatamente como um sistema jurídico, seja ele o conjunto das leis do estado, seja aquele das regras de basquete: para que sirva a algo, é preciso que (dentro de certos limites) todos estejam de acordo sobre como ele funciona.

Isso coloca a necessidade de que a linguagem seja, de fato, um sistema. Ela não é uma série de comportamentos espontâneos, variáveis com toda a liberdade por iniciativa do indivíduo e, portanto, imprevisíveis e não interpretáveis pelos outros indivíduos. Em outras palavras, é a própria natureza de um instrumento intersubjetivo e compartilhado que torna necessária a presença de 
regularidades. Nisso há uma boa razão para que a linguagem tenda a se convencionalizar e regularizar mais que muitos outros comportamentos humanos; mas isso não deve induzir ao equívoco de gerar a idéia de que a razão seja genética. A conformação do cérebro certamente permite gerenciar regularidade e recursividade, mas ela, por si só, não obrigaria a linguagem a usá-las. Externamente, ao contrário, essa necessidade é imposta com certeza.

Algo parecido subentende Searle (1972) quando afirma que "functional phenomena ... function the way they do because we assign them a certain status", e esse status requer "a system of rules", que ele chama "constitutive rules" porque "such rules do not merely regulate existing activities, ... but they create the very possibility of such activities". ${ }^{27}$

Ao inverso, mas na mesma lógica, raciocina Bybee (2005), que mostra como a estrutura e os limites da memória tornam conveniente e talvez inevitável a fixação e consolidação dos hábitos de uso em construções de acesso freqüente.

\section{Conclusões}

Exceto pelas considerações feitas na seção 8 sobre a presença de forças pragmáticas na base das modalidades com as quais a linguagem se organiza, a contribuição que esperamos ter dado ao debate sobre o inatismo lingüístico é essencialmente de natureza destruens. Contudo, ao lado de trabalhos de estudiosos como Tomasello e muitos outros, que investigam empiricamente as modalidades da aquisição da linguagem mostrando que a ela não subjaz uma GU inata, parece-nos importante indicar os pontos em que o paradigma inatista é defeituoso. Isso porque se trata de uma corrente muito influente e escutada, tanto dentro quanto, principalmente, fora da lingüística; e também porque, como acenamos preliminarmente na seção 1, os pés do colosso inatista são representados por um argumento, o da Pobreza do Estímulo, que é tão freqüentemente citado quão dado por óbvio sem justificativas verdadeiras.

Esperamos com nossos raciocínios ter contribuído para reforçar a dúvida de que os pés do colosso não sejam muito sólidos. 


\section{Notas}

${ }^{1}$ Tradução do italiano de Tommaso Raso (UFMG).

${ }^{2} \mathrm{Na}$ realidade há habilidades essenciais para o gerenciamento da linguagem que aparecem em certa medida também em muitos animais. Por exemplo, a capacidade de abstrair regularidades a partir da repetição de casos particulares não é própria somente de animais muito evoluídos, mas também de espécies "intermediárias", como os pombos (cfr. LIEBERMAN ,1991, p. 34).

${ }^{3} \mathrm{O}$ início desse debate moderno entre essas duas hipóteses pode ser colocado na conhecida interlocução entre Jean Piaget e Noam Chomsky, cujo extenso relatório está em Piattelli Palmarini (1979).

${ }^{4}$ Como alcançamos um conhecimento tão rico e específico, ou sistemas de crenças e compreensão tão intricados, quando a evidência que nos é disponibilizada é tão singela?

${ }^{5}$ Os humanos adquirem uma língua cedo na vida, sem qualquer instrução específica, aparentemente de uma maneira não interacional, com uma variação individual limitada apesar dos percursos individuais e fragmentários de experiência que sustentam o conhecimento individual da linguagem. Ainda mais importante, a compreensão precisa de fragmentos dos conhecimentos lingüísticos que adultos possuem revelam a presença massiva de situações de pobreza de estímulo: nosso conhecimento adulto da linguagem é em grande medida subdeterminado pelos dados disponíveis na infância, os quais seriam consistentes com inumeráveis gerneralizações para além daquelas que os falantes parecem, sem erro, convergirem. Essa observação empírica é de grande importância, uma vez que ela sustenta a necessidade de se postular um sistema estruturado de princípios lingüísticos prédeterminados que guiam a aquisição da linguagem; ela também leva à expectativa de uma uniformidade translingüística de todas as línguas humanas.

${ }^{6}$ A hipótese antiinatista é defendida, além do Piaget (v. nota anterior), por muitos estudiosos, entre os quais (de pontos de vista e com argumentos muito diferentes) H. Putnam, Ph. Lieberman, M. Tomasello, G. Sampson (dos quais vejam-se os trabalhos aqui citados na Bibliografia). Ao lado do Chomsky, provavelmente os defensores mais influentes da tese inatista e da presença de um módulo cerebral/ mental especificamente dedicado à linguagem são Stephen Pinker e Jerry Fodor.

${ }^{7}$ há muito pouca esperança de explicarmos o nosso conhecimento lingüístico em termos de idéias como analogia, indução, associação, procedimentos confiáveis, boas razões, ou justificativas [...] ou em termos de "mecanismos gerais de aprendizagem" [...] Devemos, aparentemente, pensar sobre o conhecimento da linguagem como um certo estado da mente/cérebro [...] uma faculdade distinta da 
mente - a faculdade da linguagem - com suas propriedades, estrutura e organização específicas, um "módulo" da mente.

${ }^{8}$ Sampson não por acaso aponta suas críticas principalmente nos trabalhos de Chomsky e de Pinker.

${ }^{9}$ Vejam-se, por exemplo, os trabalhos de Tomasello, M. Braine, P. Brooks e H. Diessel, citados aqui na bibliografia.

${ }^{10}$ Esse assunto foi tratado de maneira em parte diversa em Lombardi Vallauri (2004).

${ }^{11}$ Veja-se, por exemplo, a idéia da evolução da linguagem como exadaptação de desenvolvimentos anteriores de conexões que tornavam possíveis abstrações a modalidade cruzadas (sinestesias), avançadas por Ramachandran (2004, p. 76-83). Com exadaptação se traduz o inglês "exadaptation". Por exadaptação deve se entender um fenômeno em que uma mutação genética confere um certo tipo de vantagem a um organismo e, mais tarde, depois que ocorreram mutações sucessivas, a mutação originária se combina com elas e confere um vantagem plenamente diferente.

12 Trombetti (1905).

${ }^{13}$ A esse propósito cf., entre outros, Newmeyer (1998, p. 154-157).

${ }^{14}$ As vantagens seletivas da dotação humana para a linguagem de um ponto de vista anatômico e fisiológico são abundantemente demonstradas, por exemplo, já em Lieberman (1991, p. 57-72).

${ }^{15}$ Não é difícil ver que uma explicação pragmática é hipotetizável por quase todos os universais lingüísticos (cfr. Hawkins (1988) e Lombardi Vallauri (1999), e por quase todos os princípios da GU: somente para dar um exemplo, a Dependência da Estrutura e a coerência na ordem dos constituintes (N-Adj, N-Gen, etc.) apresentam vantagens de simplicidade de processamento. Também, as últimas versões da teoria gerativa (a assim chamada de Optimality Theory) vão claramente nessa direção. Veja-se em todo caso a seção 8 adiante.

${ }^{16}$ Uma das aberrações mais graves e mais difundidas do geneticismo está presente na crença de que se uma característica está presente em todos os indivíduos de uma comunidade, então ela deve ser codificada geneticamente. Assim, se por ventura uma dada forma lingüística básica, como sujeito/predicado aristotélicos, é um elemento de todas as línguas do mundo, então o seu uso deve ser programado geneticamente. [...] Seria relevante repetir, neste contexto, a razão pela qual este cânone máximo do geneticismo não é satisfatório: se algum traço deve ser julgado como "inato" ou geneticamente programado, então devem existir algumas pessoas que não o têm. A habilidade de detectar pelo paladar a feniltiocarbamide, por exemplo, é conhecida por ser geneticamente programada porque alguns indivíduos não a possuem. 
${ }^{17}$ Considere-se que o segundo grau na Itália dura cinco anos [N.d.T.].

${ }^{18}$ Hoekstra e Kooij (1988, p. 38).

19 (9) [2] a. Onde o João disse que tínhamos que descer do ônibu?

b. Onde o João perguntou se tínhamos que descer do ônibus?

Ambas as sentenças são gramaticais. Porém, enquanto (2a) [9a] é ambígua emrelação a uma leitura na qual where "onde" tem escopo de matriz e uma outra leitura na qual tem escopo encaixado, (2b) [9b] só pode ser interpretada como uma pergunta concernente ao local em que João fez uma pergunta específica (isso é, com escopo de matriz). Esse conhecimento está disponível para todos os falantes nativos, mas é muito improvável que tenha sido estabelecido com base em uma indução, simplesmente porque não há dados a partir dos quais uma indução pudesse ser executada. [...] A Assumpção razoável a ser feita parecer ser a de que a criança, com base nos dados relevantes que ela encontra, deve tentar fornecer uma resposta sobre o porquê de não haver escopo de encaixada para o where "onde" em (9b) [2b] e, mais genericamente, deve tentar encontrar quais as condições que são "barreiras" para a extração de palavras interrogativas. Dados como (9a) [2a] e (9b) [2b], não obstante o quão cuidadosamente sejam "armazenados", são em si mesmos insuficientes para oferecer uma resposta a essas questões, a não ser que a criança também tenha acesso aos princípios complexos da GU que determinam a (im)possibilidade da extração em outras configurações semelhantes.

O que estamos confrontando, então, é um sistema que é constante em toda a espécie e que tem propriedades que são subdeterminadas pelo ambiente. Essas são precisamente as características que levam à postulação de uma propriedade de genótipo. [...] No caso da linguagem, a distinção é feita entre uma gramática cerne presente em todas as línguas individualmente, que é determinada pelo genótipo, e uma periferia lingüística a cada língua que é responsável pela variação interlingüística.

${ }^{20}$ A questão inteira na verdade parte de Chomsky (1980): cf. Pullum e Scholz (2002, p. 39). Chomsky defende também (in Piattelli Palmarini, 1979, p. 40) que "a person might go through much or all of his life without ever having been exposed to relevant evidence"* do fato que o verbo que deve ser deslocado à esquerda em uma construção relativa é o principal. Isso porque as interrogativas que contêm uma relativa seriam raríssimas. Essa asserção é cuidadosamente confutada, por exemplo, por Pullum e Scholz (2002), e por Sampson (2002). Mas veja-se também, em favor, Legate and Yang (2002, p. 155). (*um indivíduo pode passar quase toda ou toda a sua vida sem jamais e expor à evidência relevante).

${ }^{21}$ Crianças não produzem perguntas mal formadas como (15). Destarte, aparentemente, as crianças sabem que a estrutura, e não simplesmente a propriedade 
de ordem linear mais saliente das orações, é relevante na formação de perguntas de escopo fechado (resposta sim/não). Akmajian et al. (1984, p. 470).

${ }^{22}$ Sobre o fato de que o abundante repetir-se de um padrão com exclusão de um outro é suficiente para extrair uma regra, cf. por ex. Lombardi Vallauri (2004, p. 372).

${ }^{23} \mathrm{Cf}$. a esse respeito algumas observações de Piaget em Piattelli Palmarini (Org.) (1990), e Anderson (1983).

${ }^{24}$ Cf., por exemplo, Braine and Brooks (1995), Brooks et al. (1999), Tomasello (2003, p. 178-182) com relação ao conceito de entrenchment, sobre o qual não podemos nos deter aqui.

${ }^{25}$ Cf. Cook e Newson (1988, p. 134), e também Hyams (1986).

${ }^{26}$ Cf. Hawkins (1988).

${ }^{27}$ fenômenos funcionais... funcionam da maneira em que funcionam porque nós delegamos a eles um certo status, e esse status requer "um sistema de regras" que ele chama de "regras constitutivas" porque "tais regras fazem mais do que regular atividades existentes, ... na verdade, elas criam a possibilidade de existência para tais atividades.

\section{Bibliografia}

AKMAJIAN, Adrian; DEMERS, R. A.; FARMER, A.K.; HARNISH, R.M. (1984). Linguistics. An Introduction to Language and Communication. Cambridge (Mass.): Cambridge University Press (1979).

ANDERSON, John. The Architecture of Cognition. Cambridge (Mass.): Harvard University Press, 1983.

BRAINE, M.D.S. The acquisition of language in infant and child. In: REED, C. E. (Ed.). The Learning of Language. New York: Scribners, 1971a.

BRAINE, M.D.S. On two types of models of the internalization of grammars. In: SLOBIN, D. I. (Ed.). The Ontogenesis of Grammar. New York: Academic Press, 1971b. p. 153-186.

BRAINE, M.D.S. What sort of innate structure is needed to "bootstrap" into syntax? Cognition 45, p. 77-100, 1992.

BRAINE, M.D.S.; BROOKS, P. J. Verb argument structure and the problem of avoiding an overgeneral grammar. In: TOMASELLO, M.; MERRIMAN, W. E. (Ed.). Beyond Names for Things: Young Children's Acquisition of Verbs. Hillsdale, NJ: Erlbaum, 1995. p. 353-376. 
BROOKS, Patricia; TOMASELLO, Michael. How young children constrain their argument structure constructions. Language 75, 4, p. 720-738, 1999.

BROOKS, Patricia; TOMASELLO, Michael; LEWIS, Lawrence; DODSON, Kelly. Children's overgeneralization over fixed transitivity verbs: the entrenchment hypothesis. Child Development 70, p. 1325-1337, 1999.

BYBEE, Joan. The impact of use on representation: grammar is usage and usage is grammar. LSA 2005 Presidential Address. Online at <http://www.unm.edu/ jbybee/ Bybee plenary.PDF>, January 2005, presently being revised for publication.

CAVALLI SFORZA, L. L.; MENOZZI, P.; PIAZZA, A. The History and Geography of Human Genes. Princeton (NJ): Princeton University Press, 1994.

CECCHETTO, Carlo; RIZZI, Luigi. A Naturalistic Approach to Language. In: S. NANNINI, S.; SANDKÜHLER, H. J. (Ed.). Naturalism in the Cognitive Sciences and in the Philosophy of Mind. Bern: Peter Lang, 2000. p. 117-130.

CHOMSKY, C.S. The Acquisition of Syntax in Children from 5 to 10. Cambridge (Mass.): MIT Press, 1969.

CHOMSKY, Noam. Explanatory models in linguistics. In: NAGEL, E.; SUPPES, P.; TARSKI, A. (Ed.). Logic, Methodology and philosophy of Science. Stanford: Stanford University Press, 1962. p. 528-550.

CHOMSKY, Noam. Aspects of the Theory of Syntax. Cambridge (Mass.): MIT Press, 1965.

CHOMSKY, Noam. Rules and Representations. Oxford: Blackwell, 1980.

CHOMSKY, Noam. Lectures on Government and Binding. Dordrecht: Foris, 1981a.

CHOMSKY, Noam. Principles and parameters in syntactic theory. In: HORNSTEIN, N.; LIGHTFOOT, D. (Ed.). Explanations in Linguistics. London: Longman, 1981 b. p. 32-75.

CHOMSKY, Noam. Some Concepts and Consequences of the Theory of Government and Binding. Cambridge (Mass.): MIT Press, 1982.

CHOMSKY, Noam. Knowledge of Language: its Nature, Origin and Use. New York: Praeger, 1986.

CHOMSKY, Noam. Transformational grammar: past. present and future. Language and Literature, Kyoto University, p. 33-80, 1987.

CHOMSKY, Noam. Language and Problems of Knowledge. Cambridge (Mass.): MIT Press, 1988. 
CHOMSKY, Noam. Some notes on economy of derivation and representation. In: FREIDIN, R. (Ed.). Principles and Parameters in Comparative Grammar. Cambridge (Mass.): MIT Press, 1991. p. 417-454.

CIMATTI, Felice. Ciò che non dimostra la scoperta del gene Foxp2: lingue e linguaggio fra cultura e biologia. In: Sistemi Intelligenti XIX, 1, p. 25-54, aprile 2007.

COOK, V. J.; NEWSON, M. Chomsky's Universal Grammar: An introduction. Oxford: Blackwell, 1988.

COOK, V. J.; NEWSON, Mark. Chomsky's Universal Grammar. 2nd edition. Oxford: Blackwell, 1996.

CRAIN, Stephen; NAKAYAMA, Mineharu. Structure dependence in children's language. Language 63, p. 522-543, 1987.

DIESEL, H. The acquisition of complex sentences. Cambridge (Mass.): Cambridge University Press, 2004.

FODOR, J. A. The Modularity of Mind. Cambridge (Mass.): MIT Press, 1983.

FODOR, J.A.; BEVER, T. G.; GARRETT, M. F. The Psychology of Language: An Introduction to Psycholinguistics and Generative Grammar. New York: McGraw-Hill, 1974.

GEENBERG, J. Universals of language. Cambridge (Mass): Cambridge University Press, 1966.

HAWKINS, J.A. (Ed.). Explaining Language Universals. Oxford: Blackwell. J.A. Hawkins, 1988.

HOEKSTRA, Teun; KOOIJ, J. G. The innateness hypothesis. In: HAWKINS, J.A. (Ed.). Explaining Language Universals. Oxford: Blackwell. J.A. Hawkins, 1988. p. 31-55.

HYAMS, Nina. Language Acquisition and the Theory of Parameters. Dordrecht: Reidel, 1986.

LEGATE, J. A.; YANG, C. D. Empirical reassement of poverty of stimulus arguments. The Linguistics Review, n. 19, p. 151-162, 2002.

LIEBERMAN, Philip. The Biology and Evolution of Language. Cambridge (Mass.) and London: Harvard University Press, 1984.

LIEBERMAN, Philip. Uniquely Human. The Evolution of Speech, Thought, and Selfless Behavior. Cambridge (Mass.): Harvard University Press, 1991. 
LOMBARDI VALLAURI, Edoardo. Spiegare gli universali linguistici. In: LOMBARDI VALLAURI, Luigi (Ed.). Logos dell'essere, logos della norma. Bari: Adriatica, 1999. p. 711-747.

LOMBARDI VALLAURI, Edoardo. The relation between mind and language: The Innateness Hypothesis and the Poverty of the Stimulus. The Linguistic Review 21, p. 345-387, 2004.

MEDAWAR, P. B.; MEDAWAR, J. S. Aristotle to Zoos. A Philosophical Dictionary of Biology. Cambridge (Mass.): Harvard University Press, 1983.

MORGAN, J. L. From Simple Input to Complex Grammar. Cambridge (Mass.): MIT Press, 1986.

MORO, Andrea. "Linguistica mendeliana", ovvero quali domande su genetica e grammatica? Lingue e linguaggio 1, p. 39-58, 2002.

NEWMEYER, Frederick J. Language Form and Language Function. Cambridge, Mass., MIT Press, 1988.

PIATTELLI PALMARINI, Massimo. Evoluzione, selezione e cognizione: dall' apprendimento al posizionamento di interruttori mentali. Sistemi intelligenti II, 3: p. 277-322, 1990.

PIATTELLI PALMARINI, Massimo (Ed.) Théories du langage, théories de l'apprentissage: le débat entre Jean Piaget et Noam Chomsky. Paris: Editions du Seuil, 1979.

PINKER, Stephen. Language learnability and language development. Cambridge (Mass.): Harvard University Press, 1984.

PINKER, Stephen. The Language Instinct: How the Mind Creates Language. New York: Morrow, 1994.

PULLUM, Geoffrey K.; SCHOLZ, Barbara C. Empirical assessment of stimulus poverty arguments. The Linguistic Review 19, 1-2, p. 9-50, 2002.

PUTNAM, Hilary. The 'innateness hypothesis' and explanatory models in linguistics. Synthese 17, p. 12-22, 1967.

RAMACHANDRAN, Vilayanur S. Che cosa sappiamo della mente. Milano: Mondadori, 2004.

SAMPSON, Geoffrey R. Exploring the richness of the stimulus. The Linguistic Review 19, 1-2, p. 73-104, 2002.

SAMPSON, Geoffrey R. The 'Language Instinct' Debate. London-New York, Continuum, 2005. 
SEARLE, J. Chomsky's revolution in Linguistics. In: HARMAN, G. On Noam Chomsky: critical essays. Amherst (MA): University of Massachusetts Press, 1982.

TOMASELLO, Michael. Do young children have adult syntactic competence? Cognition 74, p. 209-253, 2000a.

TOMASELLO, Michael. First steps toward a usage-based theory of language acquisition. Cognitive Linguistics 11-1/2, p. 61-82, $2000 \mathrm{~b}$.

TOMASELLO, Michael. Constructing a Language: a Usage-based Theory of Language Acquisition. Harvard University Press, 2003.

TROMBETTI, Alfredo. L'unità d'origine del linguaggio. Bologna: Treves, 1905.

ULLMAN, Michael T.; PIERPONT, Elizabeth I. Specific language impairment is not specific to language: the procedural deficit hypothesis. Cortex, 41, p. 399433, 2005. 